\title{
Perencanaan Jaringan Kerja Perakitan Blok Lambung Kapal Feri Ro-Ro 750gt Terintegrasi Sistem Perpipaan Air Tawar \& Air Laut untuk Pendingin Mesin
}

\author{
Henni Amalia ${ }^{1}$ \\ ${ }^{1}$ Teknik Perkapalan, Universitas Hasanuddin, Makassar, Indonesia \\ E-mail: ${ }^{1}$ henniamalia@gmail.com
}

\section{Kata Kunci}

Jalur kritis; jaringan kerja; kapal feri.

\begin{abstract}
Abstrak
Penjadwalan proyek merupakan salah satu elemen hasil perencanaan yang dapat memberikan informasi tentang jadwal rencana dan kemajuan proyek dalam hal kinerja sumber daya berupa tenaga kerja, peralatan, dan material. Penjadwalan proyek dengan metode jalur kritis mempertimbangkan waktu penyelesaian suatu proyek berdasarkan waktu teroptimal selesainya proyek. Penelitian ini bertujuan menghitung waktu perakitan blok lambung kapal yang terintegrasi denga sistem perpipaan. Analisa data dalam penelitian ini memakai metode jalur kritis yang terdiri dari 5 tahap, meliputi: mengidentifikasi dan mengurai komponen kegiatan, mengidentifikasi beban pekerjaan, menghitung perkiraan durasi pekerjaan, menyusun komponen kegiatan, dan mengidentifikasi jalur kritis. Dari hasil identifikasi, diperoleh durasi perakitan keseluruhan blok lambung ialah selama 1.379 jam atau 176 hari dengan durasi perakitan terlama yaitu 219 jam (44 hari) pada blok 6 dan durasi perakitan tersingkat ialah pada blok 1 yaitu 69 jam (14 hari).
\end{abstract}

Keywords critical path, Ferry vessel, network

\begin{abstract}
Project scheduling is one of the planning's result that can provide information about the schedule plan and progress of the project in terms of the performance of resources such as manpowers, equipments, and materials. Project scheduling by critical path methods considers the time to completion of a project based on the optimal time of project accomplishment. This research is purposed to calculated total duration of assembly of the hull-blok integrated with piping systems. Data analysis in this research uses the critical path method which consists of 5 stages, including: identifying the components of activities, identifying workloads, calculating the estimated duration of activities, compiling activities components, and identifying critical paths. From the results of identification, the overall assembly duration of the hull block was 1.379 hours or 176 days with the longest assembly duration is 219 hours (44 days) at block 6 and the shortest duration of assembly is at block 1 which is 69 hours (14 days).
\end{abstract}

\section{PENDAHULUAN}

Perkembangan sektor konstruksi yang diakibatkan oleh upaya pemerintah untuk membangun infrastruktur di Indonesia terjadi secara pesat. Hal ini mengakibatkan terjadinya persaingan yang ketat oleh perusahaan-perusahaan penyedia jasa konstruksi, tidak terkecuali galangan kapal sebagai penyedia jasa pembangunan dan/atau perbaikan kapal. Dalam menghadapi persaingan, suatu perusahaan dalam hal ini galangan kapal tentunya harus meningkatkan kualitas efisiensi tanpa melupakan kualitas hasil produksinya. Kualitas hasil produksi yang ingin dicapai tentu saja tidak terlepas oleh ketepatan waktu penyelesaian suatu proyek yang sesuai jadwal, disamping kesesuaian anggaran.

Keberhasilan ataupun kegagalan dari pelaksanaan proyek sering kali disebabkan kurang terencananya kegiatan proyek serta pengendalian yang kurang efektif, sehingga kegiatan proyek tidak efisien, hal ini akan menyebabkan keterlambatan, menurunnya kualitas pekerjaan, dan membengkaknya biaya pelaksanaan (Adikususma, 2017). Keterlambatan penyelesaian proyek sendiri merupakan kondisi yang sangat tidak dikehendaki karena dapat menyebabkan kerugian dalam segi waktu dan biaya. Dalam kaitannya dengan waktu dan biaya produksi, perusahaan harus bisa seefisien mungkin dalam penggunaan waktu di setiap kegiatan atau aktivitas sehingga setiap proyek dapat selesai sesuai dengan penjadwalan yang telah dirancang.

Penjadwalan proyek merupakan salah satu elemen hasil perencanaan, yang dapat memberikan informasi 
tentang jadwal rencana dan kemajuan proyek dalam hal kinerja sumber daya berupa biaya, tenaga kerja, peralatan, dan material serta rencana durasi proyek dan progres waktu untuk penyelesaian proyek (Abrar, 2010). Pada umumnya, penjadwalan proyek menggunakan estimasi durasi yang pasti. Namun, banyak faktor ketidakpastian (uncertainty) sehingga durasi masing-masing kegiatan tidak dapat ditentukan dengan pasti. Faktor penyebab ketidakpastian durasi tersebut diantaranya adalah produktivitas pekerja, cuaca dan lain-lain.

Salah satu metode yang bisa diterapkan untuk membuat penjadwalan proyek konstruksi adalah dengan menggunakan metode jalur kritis (Critical Path Methods). Penjadwalan proyek dengan metode jalur kritis ini mempertimbangkan waktu penyelesaian suatu proyek dengan biaya yang dibutuhkan untuk menyelesaikan produk tersebut.

Pada proyek pembangunan kapal penjadwalan juga menjadi salah satu instrumen terpenting selain penggunaan teknologi selama proses pembangunannya. Umumnya, galangan di Indonesia dalam membangun kapal masih menggunakan sistem HBCM (Hull Block Construction Methode) yang masih menggunakan teknologi lama. Setelah HBCM terdapat sistem pembangunan ZOFM (Zone Out-Fitting Methode) dimana pembangunan bloknya telah terintegrasi dengan sistem perlengkapan dan perpipaan yang menggunakan teknologi lebih canggih, pada tingkat lebih lanjut terdapat sistem pembangunan ZPTM (Zone Painting Methode) yang telah terintegrasi pekerjaan outfitting-nya dengan pengecatan. Penggunaan teknologi yang paling canggih dan paling mutakhir dalam proses pembangunan kapal saat ini ialah pada sistem pembangunan IHOP (Integrated Hull Construction, Outfitting, and Painting) yang mengintegrasikan peralatan dan pengecatan pada pembangunan bloknya (Murdoch, 2012). Untuk mencapai pembangunan metode IHOP, sistem pembangunan dengan sistem ZOFM dan ZPTM harus dipahami terlebih dahulu (Nippon 2007).

Penggunaan HBCM pada pembangunan kapal telah mensyaratkan perencanaan jaringan kerja yang kompleks (Astuti \& Rahmawati, 2007). Dengan tuntutan penggunaan metode pembangunan kapal yang lebih baik yaitu dengan mengintegrasikan pekerjaan lambung dengan outfitting sistem perpipaan maka persyaratan perencanaan jaringan kerjanya juga akan semakin kompleks (Maulana, 2014) (Chirillo 1982). Dengan demikian hal ini harus dilakukan agar dapat dicapai waktu pembangunan yang lebih singkat dengan biaya pembangunan kapal yang lebih sedikit, namun tetap memperhatikan unsur-unsur penting dalam pengoperasian kapal di pelabuhan (Fisu, 2018). Karenanya, penulis tertarik untuk melakukan penelitian mengenai penjadwalan pembangunan blok yang terintegrasi dengan sistem perpipaan yang dituangkan dalam judul: "Perencanaan Jaringan Kerja Perakitan Blok Lambung Kapal Feri Ro-Ro 750GT yang Terintegrasi dengan Sistem Perpipaan Air Tawar dan Air Laut untuk Pendingin Mesin".

\section{METODOLOGI PENELITIAN}

Pengambilan data diperoleh dari penelitian yang telah dilakukan sebelumnya berupa gambar-gambar konstruksi kapal Feri Ro-Ro 750 GT yang dijadikan objek penelitian.

Untuk memecahkan masalah pokok yang telah dikemukakan sebelumnya, sekaligus membuktikan, maka penulis menggunakan metode jalur kritis (Critical Path Methode atau CPM)

Adapun penggunaan metode CPM untuk membuat perencanaan jaringan kerja perakitan blok lambung kapal Feri Ro-Ro 750 GT diformulasikan dengan langkah-langkah sebagai berikut

1. Perincian komponen kegiatan

Pada langkah pertama ini, semua data-data berupa gambar konstruksi dari sumber data PT. Industri Kapal Indonesia diidentifikasi serta diuraikan menggunakan metode Product Work Breakdown Structure (PWBS) sehingga menghasilkan komponen-komponen kegiatan. Secara umum komponen kegiaan yaitu:

a. Sub-assembly atau perakitan komponen konstruksi menjadi beberapa panel. Kegitan yang dilakukan dalam proses sub-assembly yaitu pengangkatan, fit-up, dan pengelasan. Gambar konstruksi profil dibuthkan pada perakitan panel karena menunjukkan tempat pemasangan dari tiap jenis frame pada panel.

b. Assembly atau kegiatan perakitan beberapa panel menjadi sebuah blok. Sama halnya proses SubAssembly, pada proses assembly kegiatan yang dilakukan yaitu pengangkatan, fit-up, dan pengelasan.

c. Pemasangan instalasi pipa. Pada pemasangan instalasi perpipaan, jenis kegiatan yang dilakukan adalah pengangkatan, fit-up, dan pengelasan. Diagram perpipaan sangat diperlukan untuk menentukan letak dari setiap pipa-pipa dalam blok serta kapasitas pompa dari instalasi perpipaan.

2. Perhitungan Beban Kerja 
Seluruh komponen kegiatan yang telah diidentifikasi kemudian diperhitungkan berapa beban dari tiaptiap kegiatan. Adapun hasil dari pengukuran beban pekerjaan maka dihasilkan total berat dalam bentuk ton untuk pekerjaan pengangkatan, dan total beban berupa panjang untuk pekerjaan fit-up dan pengelasan (Ihsan, 2007).

3. Perkiraan waktu masing-masing kegiatan

Dari hasil beban kerja kegiatan dapat ditentukan durasi kegiatan. Pada proses ini, data yang dibutuhkan adalah data produktifitas tiap jenis kegiatan. Data produktifitas menunjukan kemampuan dari para pekerja untuk melakukan pekerjaannya tiap satuan jam. Dengan menggunkan data JO, setiap kegiatan mulai dari pengangkatan hingga pengelasan dapat diberikan perkiraan waktu penyelesaiannya. Sehingga hasil keluaran pada proses ini adalah total waktu yang dibutuhkan untuk menyelesaikan suatu pekerjaan.

4. Penyusunan tata urutan kegiatan

Penyusunan komponen-komponen kegiatan harus sesuai dengan urutan logika ketergantungan menjadi jaringan kerja. Data yang dibutuhkan dalam proses ini ialah komponen-komponen kegiatan serta total durasi yang telah diidentifikasi pada proses sebelumnya kemudian diolah sehingga didapatkan kegiatankegiatan yang telah disusun menjadi sebuah mata rantai dengan urutan yang sesuai dengan logika ketergantungan kemudian merangkainya ke bentuk diagram jaringan kerja (Network Diagram).

5. Pengidentifikasian jalur kritis

Setelah data urut-urutan kegiatan serta waktu masing-masing kegiatan dibuat, langkah selanjutnya adalah menyusun bagan jaringan kerja. Setelah bagan jaringan kerja terbentuk maka dapat ditentukan jalur kritisnya (Critical Path), waktu kritisnya serta waktu yang dibutuhkan untuk menyelesaikan suatu pekerjaan atau proyek.

Kerangka pikir merupakan alur dari proses penelitian yang telah dipaparkan sebelumnya. Adapun kerangka pikir dari penilitian ini dapat dilihat pada Gambar 3.1 adalah, sebagai berikut:

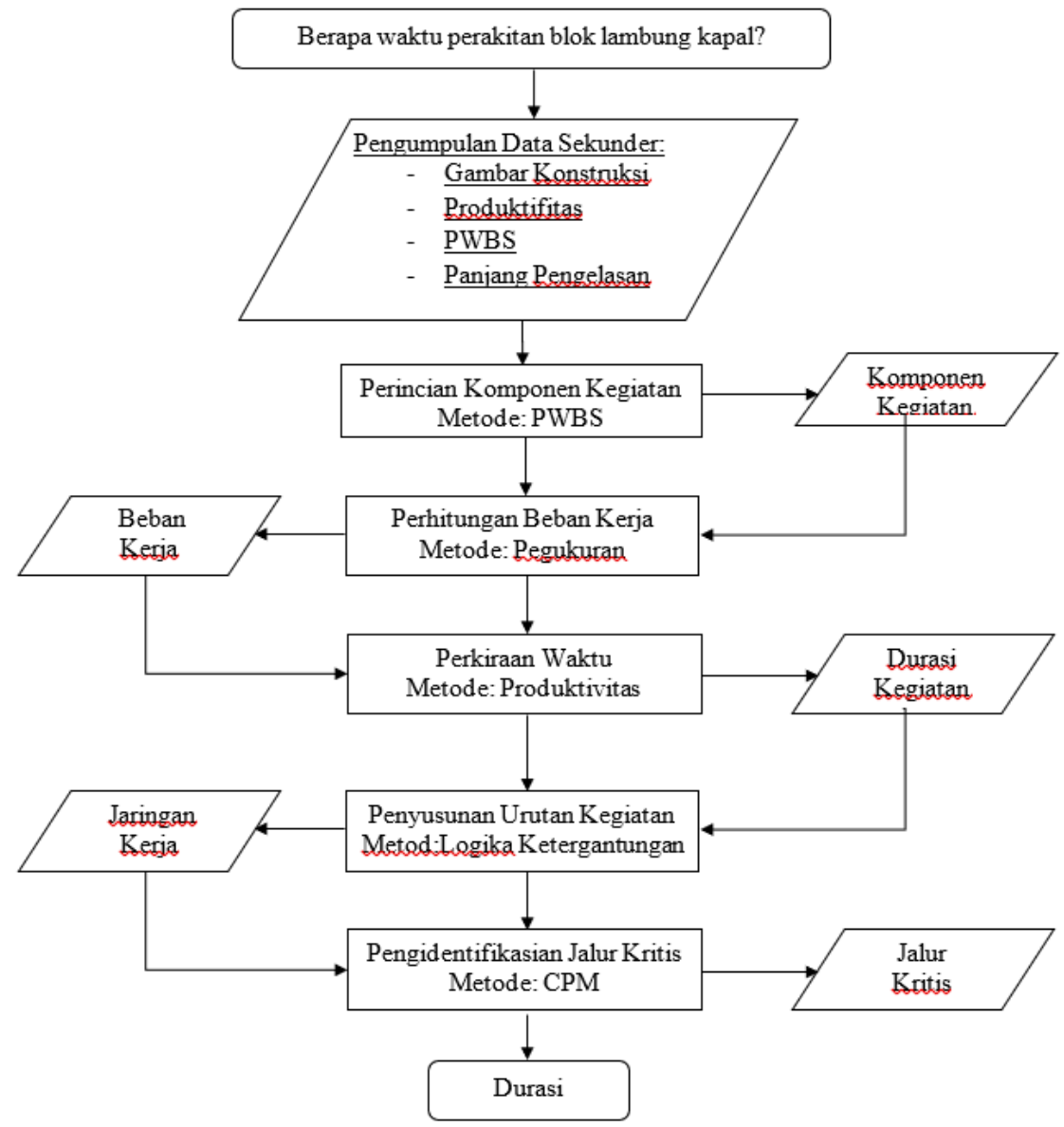

Gambar 1. Kerangka Pikir 


\section{HASIL DAN PEMBAHASAN}

\subsection{Penyusunan Urutan Kegiatan Perakitan Blok Lambung Kapal}

Pada proses penyusunan urutan kegiatan pembangunan blok kapal dimulai dari penjadwalan pekerjaan baik dari segi keterkaitan pekerjaan, waktu, tenaga, maupun pemanfaatan jadwal sebagai kontrol di dalam pelaksanaannnya. Kegiatan disusun dari perakitan panel menjadi sub-blok, sampai pada tahap block assembly. Setelah selesainya 1 Sub-blok, maka dilanjutkan dengan perakitan panel untuk sub-blok berikutnya. Adapaun Urutan dan alur perakitan salah satu sub-blok yaitu sub-blok portside Hull Structure 2 dapat dilihat pada Gambar 2. dan Gambar 3.

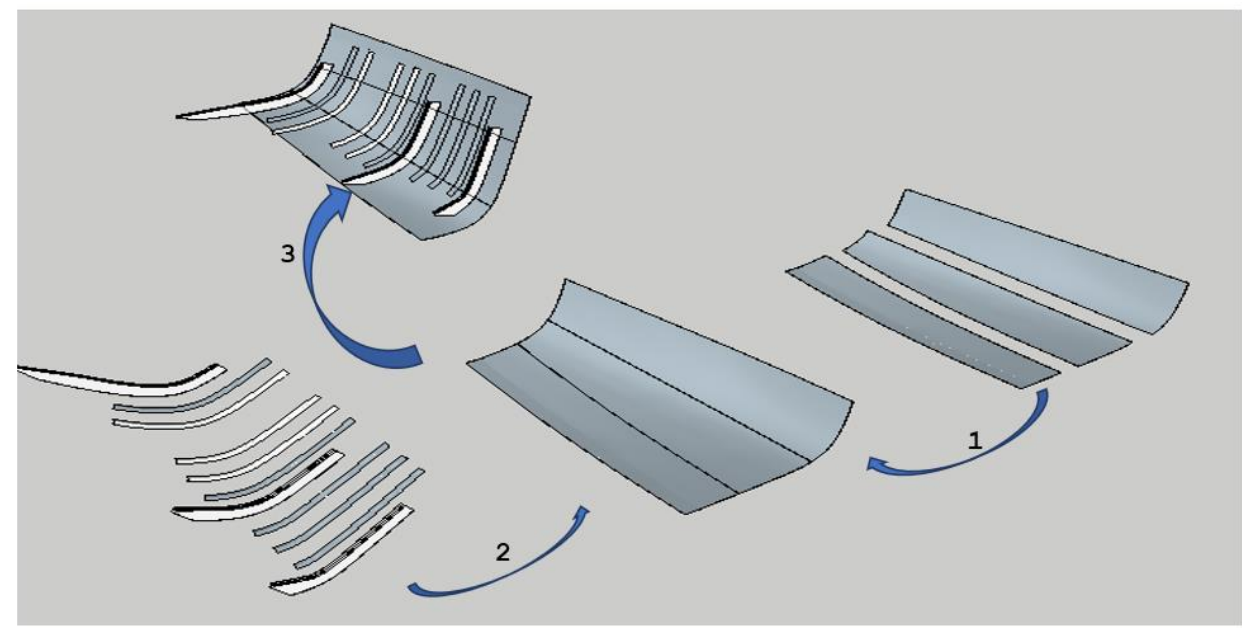

Gambar 2. Urutan Kegiatan Perakitan Sub Blok Portside Sumber : Olahan Data, 2018

Ket. (1) Fitting dan Welding antar pelat kulit,(2) Lifting Frame ke pelat kulit (3) Fitting dan welding frame ke pelat kulit

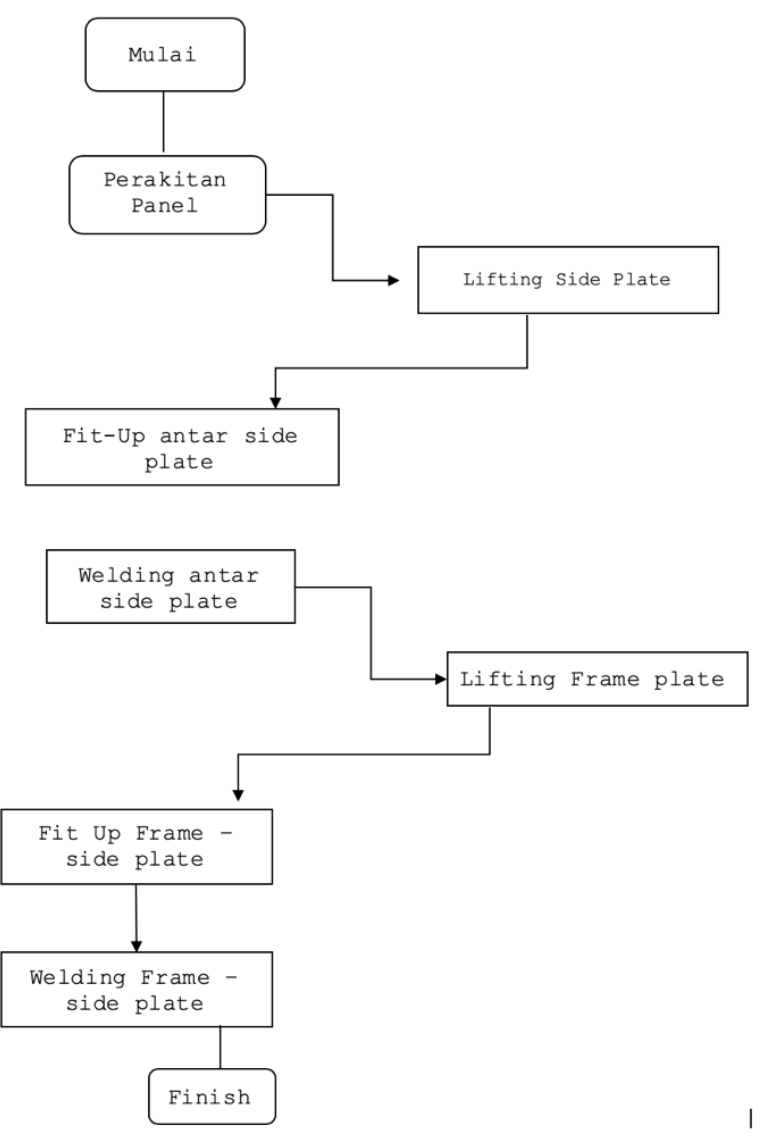


Perencanaan Jaringan Kerja Perakitan Blok Lambung

Kapal Feri Ro-Ro 750gt Terintegrasi Sistem Perpipaan Air Tawar \& Air Laut untuk Pendingin Mesin

Henni Amalia1

Gambar 3. Flowchart Perakitan Sub Blok Portside

(Sumber: Olahan Data, 2018)

Adapun berdasarkan hasil identifikasi komponen kegiatan, selanjutnya disusun menjadi sebuah mata rantai antar kegiatan sesuai dengan logika ketergantungan menjadi jaringan kerja seperti pada tabel 4.9.

Tabel 1. Logika Ketergantungan Perakitan Blok 3

\begin{tabular}{|c|c|c|c|c|}
\hline \multicolumn{2}{|c|}{ Kegiatan } & \multirow{2}{*}{$\begin{array}{c}\text { KODE } \\
\text { KegIATAN }\end{array}$} & $\begin{array}{c}\text { KEGIATAN } \\
\text { SEBELUM }\end{array}$ & $\begin{array}{c}\text { KEGIATAN } \\
\text { SESUDAH }\end{array}$ \\
\cline { 1 - 2 } 0 & 1 & $\mathrm{SB} 2$ & - & SBPP, SB4 \\
\hline 1 & 2 & $\mathrm{SBPP}$ & $\mathrm{SB} 1$ & $\mathrm{SB} 1+2$ \\
\hline 1 & 3 & $\mathrm{SB} 4$ & $\mathrm{SB} 1$ & $\mathrm{SB} 1, \mathrm{SB} 3$ \\
\hline 3 & 4 & $\mathrm{SB} 1$ & $\mathrm{SB} 4$ & $\mathrm{SB} 1+2$ \\
\hline 3 & 5 & $\mathrm{SB} 3$ & $\mathrm{SB} 4$ & $\mathrm{SB} 1+2+3$ \\
\hline 2,4 & 6 & $\mathrm{SB} 1+2$ & $\mathrm{SBPP}, \mathrm{SB} 1$ & $\mathrm{SB} 1+2+3$ \\
\hline 5,6 & 7 & $\mathrm{SB} 1+2+3$ & $\mathrm{SB} 1+2, \mathrm{SB} 3$ & SB1+2+3+4 \\
\hline 3,7 & 8 & SB1+2+3+4 & SB1+2+3, SB4 & - \\
\hline
\end{tabular}

(Sumber : Hasil olah data 2018)

Berdasarkan urutan kegiatan perakitan blok 3 di atas sesuai dengan logika ketergantungan, maka dapat diterjemahkan dalam bentuk diagaram jaringan pekerjaan (network diagram) yang merupakan visualisasi dari kegiatan yang terdapat pada perakitan Blok $3 \mathrm{KMP}$ Lakaan. Untuk lebih jelasnya dapat dilihat pada Gambar 4.

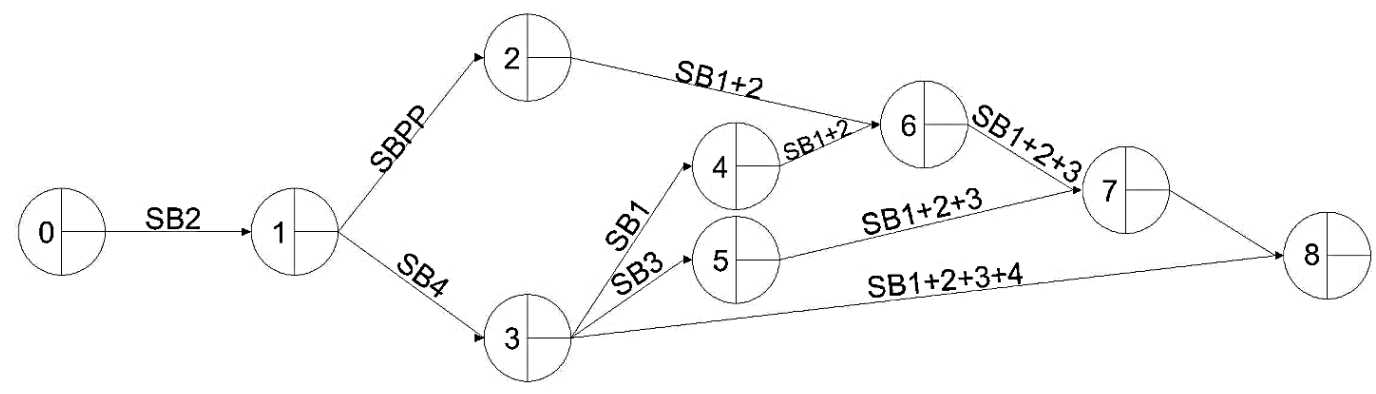

Gambar 4 Hubungan Urutan kegiatan Perakitan Blok lambung (Sumber: Hasil olah data 2018)

Keterangan:

SB1

SB2

SB3

SB4

SBPP : Instalasi Perpipaan

$\mathrm{SB} 1+2 \quad:$ Assembly $\mathrm{SB} 1+\mathrm{SB} 2$

$\mathrm{SB} 1+2+3 \quad:$ Assembly $\mathrm{SB} 1+\mathrm{SB} 2+\mathrm{SB} 3$

$\mathrm{SB} 1+2+3+4 \quad$ Assembly $\mathrm{SB} 1+\mathrm{SB} 2+\mathrm{SB} 3+\mathrm{SB} 4$

\subsection{Perhitungan Maju/Analisa Saat Paling Awal (SPA)}

Jika hanya ada kegiatan menuju sebuah peristiwa, maka saat paling awal (SPA) peristiwa tersebut adalah saat paling awal (SPA) kegiatan tesebut. Saat selesai paling awal sebuah kegiatan dengan menjumlahkan saat mulai paling awal dan lama kegiatan bersangkutan dengan durasi dalam satuan hari. Secara komulatif, untuk menentukan saat paling awal (SPA) suatu peristiwa dapat dilihat pada Gambar 5. 


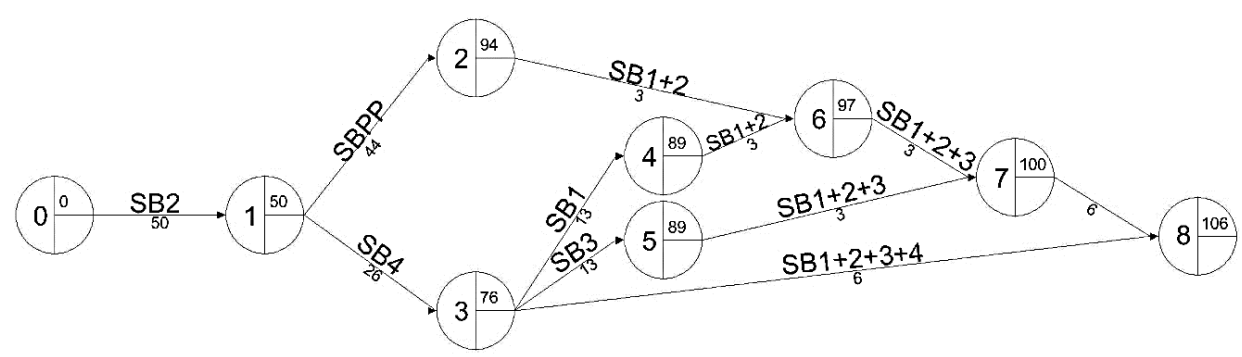

Gambar 5. Network Diagram dan Durasi Kegiatan SPA (Sumber:Hasil olah data 2018)

Berdasarkan gambar di atas maka perhitungan untuk mendapatkan nilai perhitungan maju dengan menjumlahkan kejadian awal dengan lama waktu yang telah ditentukan dapat diketahui.

Tabel yang ditunjukan dibawah ini merupakan hasil perhitungan saat paling awal (SPA) perakitan Blok 3 sampai selesai.

Tabel 2. Perhitungan SPA Perakitan Blok 3

\begin{tabular}{|c|c|l|c|c|c|}
\hline \multicolumn{2}{|c|}{ Kegiatan } & & \multirow{2}{*}{ Nama Kegiatan } & \multirow{2}{*}{$\begin{array}{c}\text { Kurun Waktu } \\
(\text { Jam) }\end{array}$} & \multicolumn{2}{c|}{ Paling Awal } \\
\cline { 1 - 1 } $\mathbf{i}$ & $\mathbf{j}$ & & Mulai & Selesai \\
\hline 0 & 1 & $\begin{array}{l}\text { Perakitan SB2 (Double } \\
\text { Bottom) }\end{array}$ & 50 & 0 & 50 \\
\hline 1 & 2 & Peraitan Perpipaan & 44 & 50 & 94 \\
\hline 1 & 3 & Perakitan SB4 (Deck) & 26 & 50 & 76 \\
\hline 3 & 4 & Perakitan SB1 (Portside) & 13 & 76 & 89 \\
\hline 3 & 5 & Perakitan SB3 (Starborard) & 13 & 76 & 89 \\
\hline 2,4 & 6 & Assembly Sb1+SB2 & 3 & 94 & 97 \\
\hline 5,6 & 7 & Assembly SB1+SB2+SB3 & 3 & 97 & 100 \\
\hline 3,7 & 8 & $\begin{array}{l}\text { Assembly } \\
\text { Sb1+SB2+SB3+SB4 }\end{array}$ & 6 & 100 & 106 \\
\hline
\end{tabular}

(Sumber:Hasil olah data 2018)

\subsection{Perhitungan Mundur/ Saat Paling Lambat (SPL)}

Jika hanya sebuah kegiatan keluar dari peristiwa, maka saat paling lambat (SPL) peristiwa tersebut adalah saat paling lambat (SPL) mulainya kegiatan tersebut. Saat mulai paling lambat sebuah kegiatan diperoleh dengan mengurangi saat paling lambat (SPL) selesainya kegiatan yang bersangkutan dengan lamanya kegiatannya.

Secara komulatif untuk menentukan saat paling lambat suatu peristiwa dapat dilihat pada Gambar 6 .

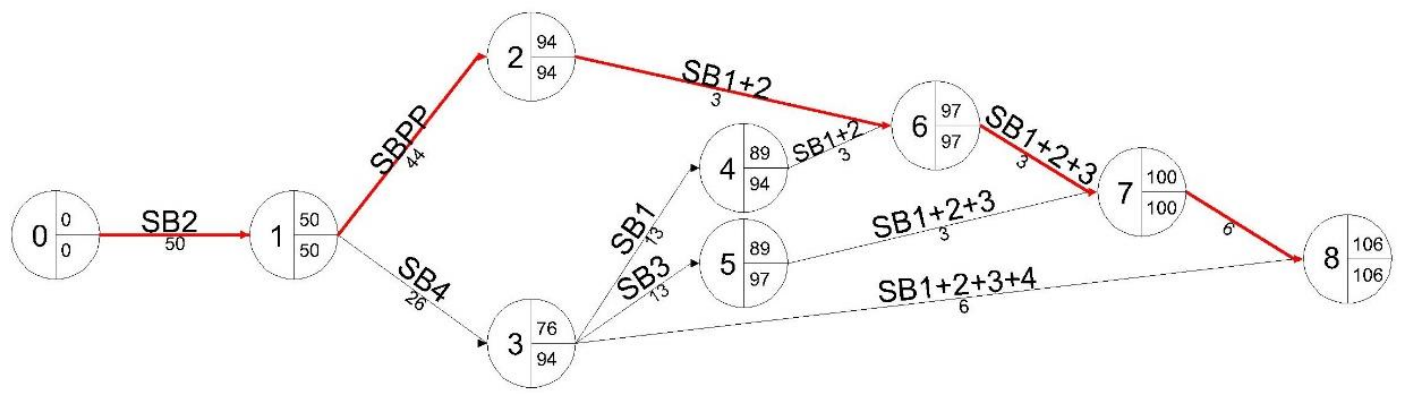

Gambar 4.8 Network Diagram dan Durasi Kegiatan SPL

(Sumber :Hasil olah data 2018)

Berdasarkan gambar 4.8 diatas maka perhitungan untuk mendapatkan nilai perhitungan saat paling 
Perencanaan Jaringan Kerja Perakitan Blok Lambung

Kapal Feri Ro-Ro 750gt Terintegrasi Sistem Perpipaan Air Tawar \& Air Laut untuk Pendingin Mesin

Henni Amalia1

lambat (SPL) dengan mengurangkan kejadian akhir dengan lama waktu yang telah ditentukan dapat diketahui. Selain itu, jalur kritis dari jaringan kerja dapat diidentifikasi pada jalur yang berwarna merah.

Tabel yang ditunjukan dibawah ini merupakan hasil perhitungan saat paling akhir (SPL) perakitan Blok 3 sampai selesai.

Tabel 3. Perhitungan SPL Perakitan Blok 3

\begin{tabular}{|c|c|l|c|c|c|c|c|}
\hline \multicolumn{2}{|c|}{ Kegiatan } & \multirow{2}{*}{ Nama Kegiatan } & \multirow{2}{*}{$\begin{array}{c}\text { Kurun Waktu } \\
(\text { Jam })\end{array}$} & \multicolumn{2}{c|}{ Paling Awal } & \multicolumn{2}{c|}{ Paling Akhir } \\
\cline { 1 - 1 } $\mathbf{i}$ & $\mathbf{j}$ & & Mulai & Selesai & Mulai & Selesai \\
\hline 0 & 1 & $\begin{array}{l}\text { Perakitan SB2 (Double } \\
\text { Bottom) }\end{array}$ & 50 & 0 & 50 & 0 & 54 \\
\hline 1 & 2 & Peraitan Perpipaan & 44 & 50 & 94 & 50 & 94 \\
\hline 1 & 3 & Perakitan SB4 (Deck) & 26 & 50 & 76 & 50 & 94 \\
\hline 3 & 4 & Perakitan SB1 (Portside) & 13 & 76 & 89 & 94 & 94 \\
\hline 3 & 5 & Perakitan SB3 (Starborard) & 13 & 76 & 89 & 94 & 97 \\
\hline 2,4 & 6 & Assembly Sb1+SB2 & 3 & 94 & 97 & 94 & 97 \\
\hline 5,6 & 7 & Assembly SB1+SB2+SB3 & 3 & 97 & 100 & 97 & 100 \\
\hline 3,7 & 8 & $\begin{array}{l}\text { Assembly } \\
\text { Sb1+SB2+SB3+SB4 }\end{array}$ & 6 & 100 & 106 & 100 & 106 \\
\hline
\end{tabular}

(Sumber: Hasil olah data 2018)

\section{Diskusi}

A. Jumlah Tenaga Kerja

Selain perencanaan jaringan kerja, jumlah tenaga kerja juga memengaruhi durasi perakitan kapal. Total keseluruhan pekerja pada blok 3 berjumlah 11 orang dengan rincian sebagai berikut:

a. Operator alat angkat 1 orang

b. Helper3 orang

c. Fitter 3 orang

d. Welder 3 orang

f. welder pipa 1 orang dan Helper pipa 1 orang

Apabila tenaga kerja dikurangi atau ditambah maka konsekuensinya adalah umur kegiatan bisa saja berkurang atau bertambah. Dan perubahan lainnya yang tejadi adalah urutan kegiatan dengan logika ketergantungan berubah maka peristiwa, kegiatan, dan jalur kritis juga ikut berubah.

\section{B. Rasio Waktu Perakitan dengan Berat Blok}

Acuan menghitung indeks beban kerja perakitan blok lambung kapal dimulai dari blok 4, karena berdasarkan rerata hitung (mean) rasio didapatkan nilai 4,49 jam/ton sedangkan rasio pada blok 4 ialah 4,53. Untuk itu penentuan indeks beban kerja perakitan blok lambung diwakilkan oleh blok 4. Oleh karena itu, untuk menentukan indeks beban kerja yaitu dengan membagi hubungan beban perakitan setiap blok (jam/ton) terhadap beban perakitan blok 4 (jam/ton).

Berdasarkan tabel 4.16 diperoleh nilai rerata hitung 4,49 jam/ton dengan hubungan beban perakitan terbesar yaitu blok 7 dan blok 8 dengan nilai 5,55 jam/ton dan hubungan beban perakitan terkecil yaitu blok 2 dengan nilai $3,10 \mathrm{jam} / \mathrm{ton}$.

Rasio waktu perakitan tiap blok dengan berat blok dapat dilihat pada tabel berikut:

Tabel 4. Rasio Waktu Perakitan dengan Berat Blok

\begin{tabular}{|c|c|c|c|c|c|}
\hline \multirow{2}{*}{ No } & \multirow{2}{*}{ Item } & Berat Blok & $\begin{array}{c}\text { Waktu } \\
\text { Perakitan }\end{array}$ & \multirow{2}{*}{ Ratio } & \multirow{2}{*}{$\begin{array}{c}\text { Indeks } \\
\text { Beban } \\
\text { Pemotongan }\end{array}$} \\
\cline { 3 - 5 } & & $\mathbf{( t o n )}$ & $\mathbf{( j a m )}$ & & $\mathbf{( 3 ) = ( 2 ) / ( \mathbf { 1 } )}$ \\
\cline { 3 - 5 } & $\mathbf{( 1 )}$ & $\mathbf{( 2 )}$ & 3,23 & 0,71 \\
\hline 1 & Blok 1 & 21,48 & 69,3 & 3,10 & 0,69 \\
\hline 2 & Blok 2 & 32,60 & 101,2 & 3,17 & 0,70 \\
\hline 3 & Blok 3 & 33,33 & 105,5 & & \\
\hline
\end{tabular}




\begin{tabular}{|l|c|c|c|c|c|}
\hline 4 & Blok 4 & 43,66 & 197,8 & 4,53 & 1,00 \\
\hline 5 & Blok 5 & 37,80 & 185,2 & 4,90 & 1,08 \\
\hline 6 & Blok 6 & 45,37 & 218,4 & 4,81 & 1,06 \\
\hline 7 & Blok 7 & 39,55 & 219,4 & 5,55 & 1,22 \\
\hline 8 & Blok 8 & 33,69 & 186,9 & 5,55 & 1,22 \\
\hline 9 & Blok 9 & 19,54 & 95,2 & 4,87 & 1,08 \\
\hline \multicolumn{7}{|c|}{ Jumlah } & $\mathbf{3 0 7 , 0 2}$ & $\mathbf{1 . 3 7 8 , 9}$ & & 0,99 \\
\hline
\end{tabular}

(Sumber: Hasil Olah Data, 2018)

\section{Produktivitas Kerja Harian}

Untuk mengetahui nilai produktivitas kerja dapat diperoleh dengan menentukan nilai gradient dari kurva $S$ berat pekerjaan dan kurva $S$ jam kerja orang dengan terlebih dahulu menentukan titik tinjauan untuk setiap kondisi. Titik tinjauan dibagi menjadi tiga titik yang mewakili tiga kondisi dimana perubahan kecekungan pada grafik terjadi. Ketiga kondisi ini ialah kondisi awal, kondisi tengah, dan kondisi akhir. Kondisi awal berada pada titik atau jam ke10 sampai ke20, kondisi tengah pada titik atau jam ke55 sampai ke65, dan jam ke90 sampai ke100 untuk kondisi akhir.

Perhitungan gradient kurva $\mathrm{S}$ berat untuk pekerjaan dengan mengambil titik tinjauan sebagai berikut:

a. Perhitungan gradient untuk kurva berat pekerjaan

Pada kondisi awal, tengah, dan akhir pekerjaan masing-masing diambil 2 titik tinjauan sebagai berikut:

- Pada kondisi awal : $(10 ; 5,89)$ dan $(20 ; 7,65)$

- Pada kondisi tengah

$:(55 ; 24,05)$ dan $(65 ; 27,21)$

- Pada kondisi akhir

$$
:(90 ; 32,62) \text { dan }(100 ; 33,33)
$$

Untuk menetukan gradient (koefisien arah garis) yang diberi simbol m, dengan menentukan 2 titik pada kurva maka dapat digunakan persamaan:

Untuk titik $(\mathrm{x} 1, \mathrm{y} 1)$ dan $(\mathrm{x} 2, \mathrm{y} 2)$, maka $\mathrm{m}=$

$$
\mathrm{m}=\frac{(\mathrm{y} 2-\mathrm{y} 1)}{(\mathrm{x} 2-\mathrm{x} 1)}
$$

Maka diperoleh nilai gradient pada masing-masing titik tinjauan, yaitu:
- Pada kondisi awal
$=0,18 \mathrm{ton} / \mathrm{jam}$
- Pada kondisi tengah
$=0,32 \mathrm{ton} / \mathrm{jam}$
- Pada kondisi akhir
$=0,07 \mathrm{ton} / \mathrm{jam}$

Nilai gradient menunjukkan produktivitas berat pekerjaan dalam satuan ton/jam.

b. Perhitungan gradient untuk kurva jam orang

Pada kondisi awal, tengah, dan akhir pekerjaan masing-masing diambil 2 titik tinjauan sebagai berikut:

- Pada kondisi awal : : $(10 ; 25,14)$ dan $(20 ; 43,96)$

- Pada kondisi tengah $\quad:(55 ; 158,85)$ dan $(65 ; 212,94)$

- Pada kondisi akhir : $(90 ; 293,81)$ dan $(100 ; 315,16)$

Untuk menetukan gradient (koefisien arah garis) yang diberi simbol $\mathrm{m}$, dengan menentukan 2 titik pada kurva maka dapat digunakan persamaan:

Untuk titik $(\mathrm{x} 1, \mathrm{y} 1)$ dan $(\mathrm{x} 2, \mathrm{y} 2)$, maka $\mathrm{m}=$

$$
\mathrm{m}=\frac{(\mathrm{y} 2-\mathrm{y} 1)}{(\mathrm{x} 2-\mathrm{x} 1)}
$$

Maka diperoleh nilai gradient pada masing-masing titik tinjauan, yaitu:
- Pada kondisi awal
: $1,88 \mathrm{jo} / \mathrm{jam}$
- Pada kondisi tengah
: $5,91 \mathrm{jo} / \mathrm{jam}$
- Pada kondisi akhir
: $2,13 \mathrm{jo} / \mathrm{jam}$

Nilai gradient menunjukkan produktivitas jam orang dalam satuan jo/jam.

c. Menentukan produktivitas kerja

Untuk menentukan produktivitas kerja dalam satuan ton/jo, dapat diperoleh dengan persamaan : 


$$
\mathrm{P}=\frac{\text { Produktivitas berat pekerjaan }\left(\frac{\mathrm{ton}}{\mathrm{jam}}\right)}{\text { Produktivitas jam orang }\left(\frac{\mathrm{jo}}{\mathrm{jam}}\right)}
$$

Sehingga diperoleh nilai produktivitas untuk masing-masing kondisi, yaitu :

- Pada kondisi awal : 0,09 ton/jo

- Pada kondisi tengah : 0,05 ton/jo

- Pada kondisi akhir : 0,03 ton/jo

Dengan nilai rata produktivitas sebesar : 0,06 ton/jo

Dengan mengasumsikan bahwa waktu produktif dalam sehari adalah 5 jam, maka produktivitas kerja harian untuk keseluruhan pekerja ialah:

Produktivitas kerja harian $\quad=0,06$ ton $/$ jo $\times 5$ jam $/$ hari

$$
=0,30 \text { ton } / \text { hari }
$$

Adapun nilai produktivitas tiap pekerja dapat dihitung melalui membagi nilai produktivitas kerja hari dengan jumlah tenaga kerja.

$$
\begin{aligned}
& \text { Produktivitas tiap pekerja }=\frac{\text { produktivitas kerja harian }}{\text { jumlah tenaga kerja }} \\
& \qquad=\frac{0,30 \text { ton } / \text { hari }}{12} \\
& =0,025 \text { ton } / \text { hari } \\
& =25 \mathrm{~kg} / \mathrm{hari}
\end{aligned}
$$

\section{KESIMPULAN DAN SARAN}

\subsection{Kesimpulan,}

Setelah melakukan analisa, maka diperoleh kesimpulan sebagai berikut:

1. Dengan mengasumsikan bahwa waktu kerja produktif selama sehari ialah 5 jam, maka diperoleh durasi perakitan setiap blok lambung KMP. Lakaan yaitu:
a. Blok $1=69,3$ jam atau 14 hari;
b. Blok $2=101,2$ jam atau 21 hari;
c. Blok $3=105,5$ jam atau 22 hari;
d. Blok $4=197,8$ jam atau 40 hari;
e. Blok $5=185,2$ jam atau 37 hari;
f. Blok $6=218,4$ jam atau 44 hari;
g. Blok $7=219,4$ jam atau 44 hari;
h. Blok $8=186,9$ jam atau 38 hari;
i. Blok $9=95,2$ jam atau 19 hari.

2. Jaringan kerja untuk tiap blok memiliki jaringan kritis yang disusun oleh kegiatan-kegiatan kritis. Adapun kegiatan-kegiatan kritis perakitan tiap blok lambung ialah:
a. Blok 1 = Perakitan SB2-Bottom, Perakitan SB5-Bulkhead, Perakitan SB4-Deck, dan Join Blok1
b. Blok 2 = Perakitan SB2-Bottom, Perakitan SB4-Deck, Perakitan SB1-Portside, dan Join Blok2
c. Blok 3 = Perakitan SB2, Perakitan SBPP, Join Blok3
d. Blok 4 = Perakitan SB1-PSide, Perakitan SB1-Pbottom, Join SB1, Perakitan SB2-Double Bottom, Perakitan SB3-PSide, Perakitan SB3-Pbottom, Join SB3, Perakitan SB4-Deck, dan Join Blok4
e. Blok 5 = Perakitan SB1-PBulkhead, Perakitan SB1-Pbottom, Join SB1, Perakitan SB2-Double Bottom, Perakitan SB3-PBulkhead, Perakitan SB3-Pbottom, Join SB3, Perakitan SB4-Deck, dan Join Blok4
f. Blok 6 = Perakitan SB1-Portside, Perakitan SB4-Deck, Perakitan SB5-Trans. Bulkhead, dan Join Blok6
g. $\quad$ Blok 7 = Perakitan SB1-Portside, Perakitan SB2-Double Bottom, dan Join Blok7
h. Blok 8 = Perakitan SB2-Double Bottom, Perakitan SB4-Deck, Perakitan SB5-Bulkhead, dan Join Blok8
i. $\quad$ Blok 9 = Perakitan SB1-Portside, Perakitan SB2-Double Bottom, Perakitan SB3-Starboard Side, Perakitan SB4-Deck, dan Join Blok 9




\subsection{Saran}

Penelitian ini hendaknya dilanjutkan dengan melengkapi sistem perpipaan yang lainnya serta perhitungan biaya perakitan dan sebaiknya menggunakan data produktifitas dari PT. IKI Makassar.

\section{DAFTAR PUSTAKA}

Adikusuma, Trian. 2017. Korelasi Antar Berat Dengan Beban Pekerjaan Perakitan Grand Blok Kapal Ferry Roro 750GT. Skripsi. Universitas Hasanuddin. Makassar.

Astuti, Rahmawati Yuli. 2007. Penerapan Analisis Jaringan Kerja Untuk Optimalisasi Perencanaan Produksi Dengan Metode Jalur Kritis. Skripsi. Universitas Sanata Dharma. Yogyakarta.

Chirillo, L.D. 1982. Pipe Piece Family Manufacturing. U.S. Department of Transportation. Washington.

Fisu AA. (2018). Analisis Kebutuhan Sisi Laut Pelabuhan Terminal Khusu PLTGU Lombok. PENA TEKNIK: Jurnal ilmiah Ilmu-ilmu Teknik 3(2) 197-206.

Ichsan, Maulana. 2007. Studi Produktifitas Kerja Juru Las (Posisi Pengelasan Vertikal) Ferry RoRo 300GRT. Skripsi. Universitas Hasanuddin. Makassar.

Maulana, Fatwa. 2014. Rancangan Blok Lambung Kapal (HBCM) Terintegrasi Dengan Sistem Perpipaan (ZOFM) Pada Kapal SPOB 2x335 HP. Skripsi. Universitas Hasanuddin. Makassar.

Murdoch, Eric. 2012. A Master's Guide to: Ships'Piping. The Standard. London.

Nippon Kaiji Kyokai. 2007. Outline of Ship-Hull Part. Tokyo.

Taggart, Robert. 1980. Ship Design and Construction. The Society of Naval Architects \& Marine Engineers. New York.

Y. Okayama, L. D. Chirillo. 1982. The National Shipbuilding Research Program Product Work Breakdown Structure. Proceeding NSRP. 